\title{
PENILAIAN TINGKAT USABILITAS PADA ELEKTRONIK REPOSITORY PERPUSTAKAAN UNIVERSITAS ISLAM NEGERI (UIN) SUNAN KALIJAGA YOGYAKARTA
}

\author{
Arina Faila Saufa ${ }^{1^{*}}$

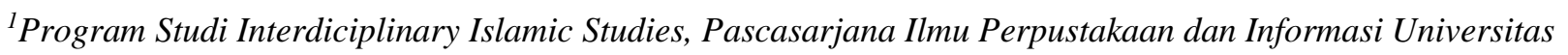 \\ Islam Negeri Sunan Kalijaga, Yogyakarta \\ $\left.{ }^{*}\right)$ Korespondensi: arinasaufan @ gmail.com
}

\begin{abstract}
[Title: Assessment of Usability Levels on The Electronic Repository of Universitas Islam Negeri Sunan Kalijaga Library] Currently, digital-based of collection services have been developed by libraries in the form of institutional repository. In addition, to providing convenience and effectiveness to the user, this electronic repository service also needs to be evaluated, so that the library knows the performance of the service. The study entitled "Assessment of usability level in electronic repository Library of Sunan Kalijaga Islamic State University" aims to assess the performance of electronic repository by using some indicators of usability level. The method used in this research is descriptive quantitative. The population used is the average user of e-repository during the last 3 months from July to September 2017. While the sampling technique using random sampling and using slovin formula to determine the number of samples. In measuring the level of reusability researchers used several indicators include; (1) usefulness, (2) efficient, and (3) effective, (4) learnability, and (5) satisfaction. Based on the results of questionnaire / questionnaire obtained the following results; as much as 36.9\% of respondents agreed that e-repository meets the criteria of usefulness, $28.2 \%$ of respondents stated efficient, and $43.4 \%$ said effective. As for the indicators learnability there is only as much as $13 \%$ of respondents as well as indicators of satisfaction that only get $13 \%$ of respondents. From these results it can be concluded that the e-repository Yogyakarta Sunan Klaijaga only meet the indicator usefulness, efficient, and effective, but does not meet the learnability and satisfaction indicators.
\end{abstract}

Keywords: Electronic repository; usability assessment; college library

\begin{abstract}
Abstrak
Saat ini, layanan koleksi berbasis digital telah banyak dikembangkan oleh perpustakaan yaitu dalam bentuk institutional repository. Selain memberikan kemudahan dan keefektivan kepada pemustaka, layanan electronic repository ini juga perlu untuk dievaluasi agar perpustakaan mengetahui performa dari layanan tersebut. Penenelitian yang berjudul "Penilaian tingkat usabilitas pada elektronik repository perpustakaan Universitas Islam Negeri (UIN) Sunan Kalijaga Yogyakarta" ini bertujuan untuk menilai kinerja dan performa electronic repository perpustakaan perguruan tinggi dengan menggunakan beberapa indikator tingkat usabilitas. Metode yang digunakan dalam penelitian ini merupakan deskriptif kuantitatif. Pengumpulan data yang dilakukan oleh peneliti melalui observasi di lapangan, penyebaran kuesioner, dan wawancara untuk lebih mendalami. Populasi yang digunakan merupakan rata-rata pengguna e-repository selama 3 bulan terakhir sejak bulan Juli hingga September 2017. Sedangkan teknik pengambilan sampel menggunakan random sampling dan mengunakan rumus slovin untuk menentukan jumlah sampel. Dalam mengukur tingkat usabilitas peneliti menggunakan beberapa indikator meliputi; (1) usefulness, (2) efisien, (3) efektif, (4) learnability, dan (5) kepuasan. Berdasarkan hasil penyebaran angket/kuesioner didapatkan hasil sebagai berikut; sebanyak 36,9\% responden setuju bahwa e-repository ini memenuhi kriteria usefulness, 28,2\% responden menyatakan efisien, dan 43,4\% menyatakan efektif. Sedangkan untuk indikator learnability hanya ada sebanyak $13 \%$ responden begitu juga dengan indikator kepuasan yang hanya mendapatkan 13\% responden. Dari hasil ini dapat disimpulkan bahwa e-repository UIN Sunan Klaijaga Yogyakarta hanya memenuhi indikator usefulness, efisien, dan efektif, namun tidak memenuhi indikator learnability dan kepuasan.
\end{abstract}

Kata kunci: Elektronik repository; penilaian kegunaan; usability; perpustakaan perguruan tinggi 


\section{Pendahuluan}

Kemajuan Teknologi Informasi saat ini telah mengubah akses informasi menjadi sangat mudah dan terbuka. Keterbukaan dan kemudahan akses informasi ini juga dengan cepat membantu perpustakaan dalam menyediakan akses informasi kepada pengguna. Hal ini seperti diperlihatkan pada fasilitas perpustakaan digital yang sudah banyak dikembangkan oleh Perpustakaan Perguruan Tinggi berupa elektronik repository (e-repository). Witten dan Bainbridge (2003: 28) menyatakan bahwa fokus utama dari perpustakaan digital di lingkungan perguruan tinggi adalah pada penelitian dan pendidikan. Sehingga dapat dikatakan bahwa penyediaan fasilitas sumber informasi elektronik pada e-repository perpustakaan perguruan tinggi adalah menyediakan akses informasi untuk kebutuhan penelitian dan pendidikan di lingkungan perguruan tinggi tersebut.

Selain menyediakan akses sumber informasi elektronik, e-repository juga perlu menekankan pada inovasi fasilitas perpustakaan digital. Hal ini bisa diukur dengan melihat performa dari sistem perpustakaan digital tersebut melalui perspektif pengguna, pemenuhan kebutuhan pengguna, dan kegunaan (usability) perpustakaan digital tersebut kepada pengguna. Peningkatan performa dan layanan melalui perspektif pengguna ini akan sangat membantu perpustakaan dalam memberikan pelayanan digital yang maksimal sehingga mampu memberikan kepuasan saat digunakan.

Keberadaan perpustakaan digital berupa e-repository ini sangat memudahkan pengguna dalam melakukan pencarian informasi. Pengguna tidak lagi harus datang ke perpustakaan untuk mencari informasi, namun mereka dapat menggunakan e-repository melalui penelusuran dengan katalog online yang disediakan perpustakaan. Blandford (2004) mengungkapkan bahwa motivasi dibangunnya perpustakaan digital adalah untuk mengurangi masalah penyimpanan koleksi, melestarikan koleksi yang berharga, dan memenuhi persepsi bahwa digitasi akan mampu mengembangkan akses. Namun dari beberapa motivasi ini tidak satupun yang menjelaskan bagaimana perpustakaan digital harus dirancang dengan baik agar benar-benar berguna dan bermanfaat.

Hal inilah yang membuat kegiatan penilaian terhadap e-repository menjadi sebuah prioritas, khususnya dalam hal kegunaan (usability) dari sistem tersebut kepada pengguna. Ini seperti halnya dikatakan oleh (Theng et.al, 2000: 238) bahwa pekerjaan kecil yang harus dilakukan oleh perpustakaan adalah memahami tujuan dan kegunaan dari perpustakaan digital. Borgman at.al (2000: 391) juga mengatakan bahwa relatif sedikit perpustakaan yang melakukan evaluasi tentang kegunaan dari perpustakaan digital dalam konteks apapun. Dari beberapa pernyataan tersebut dapat disimpulkan bahwa evaluasi tingkat kegunaan (usability) pada perpustakaan digital e-repository merupakan hal yang penting, karena aspek kegunaan ini dapat digunakan untuk memahami kemampuan dari sistem saat bertatap muka dengan pengguna dan bagaimana sistem mendukung kebutuhan mereka.

Perpustakaan Universitas Islam Negeri (UIN) Sunan Kalijaga Yogyakarta telah mengembangkan fasilitas e-repository sejak tahun 2007 lalu. Perpustakaan ini berkomitmen untuk memudahkan akses 
koleksi digital yang dihasilkan oleh sivitas akademika kepada masyarakat luas. Koleksi digital yang disediakan diantaranya; skripsi, tesis, disertasi, laporan penelitian, dan laporan hasil kuliah kerja praktik di lapangan. Selain itu, perpustakaan digital ini juga menyediakan artikel-artikel ilmiah, jurnal, prosiding, materi perkualiahan, hasil konferensi ilmiah, dan koleksi lainnya yang tidak hanya disajikan dalam format teks namun juga foto dan video.

Keberadaan fasilitas e-repository di lingkungan UIN Sunan Kalijaga diharapkan mampu memberikan kemudahan akses dan memberikan kegunaan yang maksimal kepada seluruh pengguna perpustakaan. Namun untuk melihat seberapa tingkat kegunaan (usability) dari sistem tersebut haruslah dilakukan sebuah penilaian yang terukur. Salah satu cara untuk dapat menilai sistem ini dengan lebih obyektif adalah dengan mengambil perspektif dari pengguna, dalam hal ini adalah mahasiswa UIN Sunan Kalijaga, staff atau dosen, dan peneliti di lingkungan Universitas. Oleh karena itu, peneliti melakukan penilaian (assessment) terhadap e-repository UIN Sunan Kalijaga pada tingkat kegunaan atau usabilitas.

\section{Tinjauan Literatur}

\subsection{Penilaian Kegunaan Perpustakaan Digital}

Pada konteks perpustakaan digital, Reeves et.al (2005: 83) mendefinisikan usabilitas sebagai efektivitas, efisiensi, dan kepuasan perseorangan saat mengakses dan menggunakan berbagai sumber di perpustakaan digital. Sedangkan Marchionini et.al (2003: 309) menekankan bahwa kebutuhan informasi pengguna merupakan pusat perhatian suatu perpustakaan. Ia juga menambahkan bahwa seluruh desain, implementasi, dan evaluasi perpustakaan digital harus didasarkan kepada kebutuhan informasi pengguna, karakteristik, dan kondisi masyarakat yang akan menggunakan layanan tersebut. Sehingga dengan melakukan evaluasi perpustakaan digital pada aspek kegunaan (usability) merupakan hal yang penting untuk mengetahui sebarapa jauh kemampuan dari sistem saat bertemu dengan kebutuhan informasi pengguna.

Arms (2000) berpendapat bahwa tingkat kegunaan (usability) terdiri dari beberapa aspek, meliputi design interface, desain fungsional, data dan metadata, serta jaringan dan sistem komputer. Sementara, Jeng (2005: 98) menyatakan bahwa usability adalah sebuah properti dari sistem perpustakaan digital dimana seluruh komponen harus bekerja bersama-sama secara efisien, efektif, dan memberikan pelayanan yang mudah kepada pengguna. Penilaian ini perlu didasarkan pada perspektif pengguna bagaimana sistem tersebut berguna dan mudah digunakan bagi mereka. Pengukuran berbasis pengguna untuk mengevaluasi perpustakaan digital ini sangat penting dalam memahami sebarapa baik pelayanan sistem dalam memenuhi kebutuhan mereka. Long (2002) mengakui bahwa evaluasi seperti ini sangat cocok untuk mengidentifikasi pengguna dan kebutuhan informasi mereka. 


\subsection{Kriteria Penilaian Usability}

Beberapa atribut atau dimensi dari usabilitas telah banyak diusulkan para ahli sebagai pemandu dalam pengukuran. Diantaranya seperti Nielsen (1993: 156) yang mengusulkan dimensi usabilitas meliputi learnability, efficiency, memorability, errors, dan satisfaction. Ahli lain menyebutkan bahwa dimensi usabilitas meliputi effectiveness, efficiency, satisfaction, security, dan learnability (Abran et.al, 2003: 327). Sementara itu, Jeng (2005: 118) memberikan model ilustrasi usabilitas yang meliputi effectiveness, efficiency, dan satisfaction. Kemudian ia juga memberikan pengukuran pada satisfaction dengan ukuran mudah digunakan, mempunyai manajamen informasi yang baik, clear labelling, visual appearance, content, dan error correction.

\section{a. Usefulness}

Usefulness meliputi isi/konten dan layanan yang ditawarkan oleh sebuah sistem dan seberapa dekat mereka bertemu dengan permintaan pengguna, (Savolainen, 2008: 276). Aspek ini lebih memperhatikan pada konten/isi yang disediakan oleh sebuah layanan informasi yang bisa memberikan manfaat bagi penggunanya. Nilai manfaat yang berikan di sini sangat berkaitan dengan seberapa besar informasi tersebut dapat memenuhi kebutuhan pencari informasi.

\section{b. Relevan}

Relevansi adalah salah satu aspek fundamental terpenting dalam kegiatan temu kembali informasi (Tombros et.al, 2004: 329). "Ketika relevansi berkaitan dengan konten, maka relevansi dapat dianggap seperti obyektivitas, dan subyektivitas berhubungan dengan pengalaman dan kebutuhan pengguna," (Thornley and Gibb, 2007: 761). Pada konteks usefulness, relevansi dikaitkan dengan seberapa baik sistem menampilkan keunggulan pada permintaan pengguna dan seberapa baik sistem menampilkan informasi yang diinginkan oleh pengguna.

\section{c. Reliability}

Menurut Yang et.al (2005: 578) reliability merupakan keakuratan, keandalan, konsistensi dari informasi, dan kredibilitas. Sebuah kredibilitas akan menentukan apakah sumber informasi tersebut dapat diterima dan digunakan oleh pengguna (Burgoon et.al, 2000: 553). Sebuah perpustakaan yang menyediakan elektronic repository dengan sumber-sumber informasi yang andal akan lebih banyak diminati oleh pengguna, begitu pula sebaliknya jika sumber-sumber informasi kurang kredibel maka pengguna akan ragu untuk memanfaatkannya.

\section{d. Akurat}


Pipino et.al (2002: 214) menyatakan bahwa keakuratan adalah ketika informasi tersebut cukup up to date dan berasal dari sumber informasi yang dapat dipertanggungjawabkan untuk digunakan sesuai permintaan pengguna. Up to date berarti informasi yang disediakan bukan merupakan informasi lama sedangkan informasi serupa yang terbaru sudah beredar di mana-mana. Sementara informasi tersebut akurat berarti benar dan dapat dipertanggungjawabkan oleh sumbernya.

\section{e. Efisien}

Efisien sangat berkaitan dengan penyelesaian produktivitas pengguna, khususnya pada perhatian tertentu (Dicks, 2002: 26). Dalam hal ini Petrelli (2008: 25) menambahkan bahwa efisien berkaitan dengan waktu penyelesaian tugas yang diukur dengan pengukuran valid. Namun pendapat lain mengatakan bahwa waktu tidak cocok sebagai alat ukur sebuah sistem karena dapat dipengaruhi oleh faktor-faktor eksternal seperti kecepatan koneksi dan lalu lintas jaringan yang dapat mempengaruhi waktu yang dibutuhkan sistem dalam menampilkan permintaan pengguna (Benbunan - Fich, 2001).

\section{f. Efektif}

Efektivitas berkaitan dengan penyelesaian permintaan pengguna yang berhubungan dengan kesuksesan tujuan pengguna. Hal ini yang menjadi dimensi adalah minimnya eror yang dialami pengguna dan kelengkapan informasi. Semakin lengkap dan akurat sumber informasi yang diberikan, maka semakin tinggi pula nilai kualitasnya.

\section{g. Learnability}

Learnability merupakan kemampuan dari sebuah sistem untuk memenuhi pengguna hingga mereka merasa bahwa sistem tersebut telah menyediakan kebutuhan dengan baik dan mudah dipelajari (Seffah, 2006: 160). Kemudian Nielsen (1993: 216) menambahkan bahwa learnability sering dikaitkan dengan sebagai aspek fundamental dari usability, pembelajaran dari sebuah sistem adalah pengalaman pertama pengguna.

\section{h. Kepuasan}

Menurut Rogers (2008: 276) kepuasan pengguna melibatkan atitut pengguna dan persepsi seberapa pengguna bisa menikmatinya (enjoyable) saat menggunakannya. Jeng (2005: 99) menambahkan bahwa kepuasan berkaitan dengan wilayah mudah digunakan, informasi yang terorganisasi, clear labelling, tampilan visual, konten yang diukur oleh skala dan kuesioner.

\section{Metode Penelitian}

\subsection{Desain Penelitian}

Penelitian ini merupakan jenis penelitian kuantitatif dengan pendekatan deskriptif. Desain ini dipilih oleh peneliti karena sangat memungkinkan digunakan untuk sebuah penilaian dari sudut pandang persepsi 
pengguna. Oleh karena itu peneliti mengambil desain ini untuk menilai dari sudut pandang pengguna tentang elektronik repository di Universitas Islam Negeri Sunan Kalijaga Yogyakarta.

\subsection{Populasi dan Sampel}

Menurut Arikunto (2010: 63) populasi merupakan keseluruhan dari subyek penelitian. Sedangkan sampel adalah bagian dari populasi yang memiliki ciri-ciri atau keadaan yang akan diteliti (Martono, 2012). Populasi dalam penelitian ini adalah rata-rata pengguna e-repository perpustakaan UIN Sunan Kalijaga Yogyakarta yang diambil selama 3 (tiga) bulan terakhir yaitu mulai bulan Juli - September 2017 yang berjumlah 575 pengguna. Peneliti menggunakan rumus slovin untuk menentukan jumlah sampel yang diambil, yaitu:

$$
\mathrm{n}=\frac{\mathrm{N}}{\left(1+\mathrm{N}(\mathrm{e})^{2}\right)}
$$

\section{Keterangan:}

$\mathrm{n}=$ Jumlah sampel

$\mathrm{N}=$ Jumlah populasi

$\mathrm{e}=$ Jumlah kelonggaran eror yang bisa ditelolelir ( dalam penelitian ini peneliti menggunakan angka $2 \%$ atau 0,02$)$

575

$$
\begin{aligned}
\mathrm{N} & =\frac{575}{(1+575(0,02))} \\
& =\frac{(1+11,5)}{575} \\
& =\frac{12,5}{} \\
& =46
\end{aligned}
$$


Dari penghitungan rumus slovin tersebut, maka dapat dikatakan bahwa jumlah sampel yang peneliti gunakan dalam penelitian ini berjumlah 46 sampel. Sementara teknik pengambilan sampel yang peneliti gunakan yaitu random sampling, artinya semua populasi mempunyai kesempatan yang sama untuk menjadi sampel.

\subsection{Teknik Pengumpulan Data}

Menurut Arikunto (2010: 74) pengumpulan data adalah suatu usaha sadar untuk mengumpulkan data yang dilakukan secara sistematis dengan prosedur yang standar. Pada penelitian ini menggunakan teknik pengmpulan data berupa observasi, interview/wawancara, dan angket/kuesioner.

\subsection{Skala Data}

Penelitian ini menggunakan skala ukur ordinal. Skala ukur ordinal adalah mengurutkan data dari tingkat yang paling rendah ke tingkat yang paling tinggi atau sebaliknya dengan interval yang tidak harus sama (Umar, 2007: 56). Sedangkan Sulistyo-Basuki (2006: 62) mengatakan bahwa skala ordinal adalah skala yang menentukan posisi relatif dari objel atau individual menyangkut dengan cici tertentu tanpa ada implikasi terhadap jarak antara masing-masing posisi.

Tabel 1. Skala Penelitian (Sulistyo-Basuki, 2006)

\begin{tabular}{|l|l|}
\hline Jawaban & Nilai \\
\hline Sangat setuju & 5 \\
\hline Setuju & 4 \\
\hline Ragu-ragu & 3 \\
\hline Tidak setuju & 2 \\
\hline Sangat tidak setuju & 1 \\
\hline
\end{tabular}

\subsection{Analisis dan Penyajian Data}

Feuerstein (1986) menyatakan bahwa tabel dan grafik sangat membantu untuk menunjukkan informasi kunci dengan cepat, membuat lebih mudah dalam menampilkan perbandingan, menunjukkan pola dan tren dan mampu mengambil sedikit ruang. Oleh karena itu peneliti akan memanfaatkan metode penyajian data tersebut pada pembahasan penelitian kali ini. Analisis yang digunakan oleh peneliti adalah dengan mengukur seberapa usabilitas dari e-repository UIN Sunan Kalijaga Yogyakarta melalui evaluasi perspektif pengguna yang menggunakan indikator/dimensi sebagai berikut: 


\section{Usefulness}

2. Efisien

3. Efektif

4. Learnability

5. Kepuasan

\section{Analisis Data dan Pembahasan}

\subsection{Analisis Data}

Dari hasil penyebaran kuesioner/angket kepada seluruh responden, maka hasil penghitungan data dapat disajikan sebagai berikut:

Tabel 2. Hasil penghitungan data jawaban kuesioner

\begin{tabular}{|l|l|l|l|l|l|}
\hline INDIKATOR & $\begin{array}{l}\text { SANGAT } \\
\text { SETUJU= 5 }\end{array}$ & SETUJU= 4 & $\begin{array}{l}\text { KURANG } \\
\text { SETUJU=3 }\end{array}$ & $\begin{array}{l}\text { TIDAK } \\
\text { SETUJU= 2 }\end{array}$ & $\begin{array}{l}\text { SANGAT TIDAK } \\
\text { SETUJU= 1 }\end{array}$ \\
\hline USEFULNESS & $21,7 \%$ & $36,9 \%$ & $17,3 \%$ & $13 \%$ & $10,8 \%$ \\
\hline EFISIEN & $15,2 \%$ & $28,2 \%$ & $26 \%$ & $17,3 \%$ & $13 \%$ \\
\hline EFEKTIF & $10,8 \%$ & $43,4 \%$ & $13 \%$ & $21,7 \%$ & $10, \%$ \\
\hline LEARNABILITY & $10,8 \%$ & $13 \%$ & $17,3 \%$ & $41,3 \%$ & $17,3 \%$ \\
\hline KEPUASAN & $13 \%$ & $15,2 \%$ & $23,9 \%$ & $32,6 \%$ & $15,2 \%$ \\
\hline
\end{tabular}

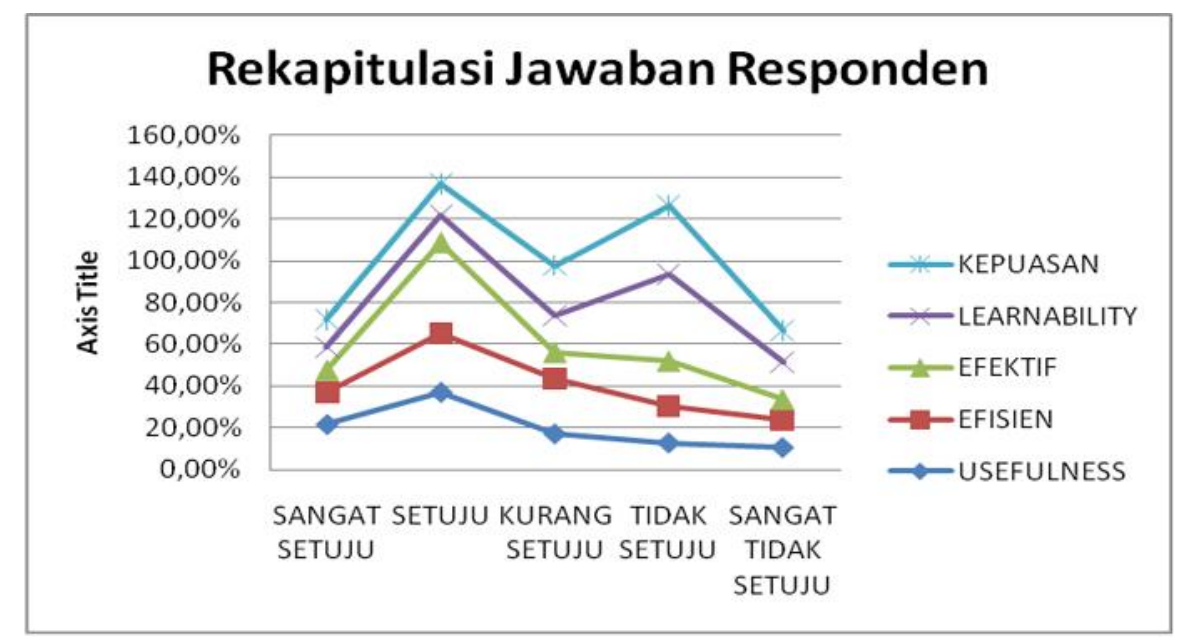

Gambar 1. Diagram Rekapitulasi Jawaban Responden

\subsection{Pembahasan}

\section{a. Usefulness}

Pada indikator usefulness, elektronik repository perpustakaan UIN Sunan Kalijaga Yogyakarta diukur dengan beberapa indikator meliputi relevansi dan keakuratan. Barry and Schambler (1998) 
menyatakan bahwa relevansi sangat berhubungan dengan penemuan kembali informasi yang sesuai dengan keinginan penguna. Sedangkan keakuratan dilihat dari kebaruan informasi yang disajikan. Dari sebanyak 46 angket yang diberikan kepada responden didapatkan hasil bahwa rata-rata responden menyatakan setuju dengan paramater tersebut. Artinya, mereka sepakat jika e-repository ini memenuhi kriteria usefulness. Hal ini dapat dilihat dari jumlah responden yang memilih setuju sebanyak 17 responden atau sebanyak 36,9\%. sedangkan responden yang mengatakan tidak setuju hanya 6 orang atau sebanyak $13 \%$.

Seorang responden yang menjawab setuju berpendapat bahwa e-repository yang dimiliki oleh perpustakaan UIN Sunan Kalijaga sudah memberikan cukup manfaat dalam penyediaan informasi. "Diantaranya untuk mengakses jurnal nasional maupun internasional sehingga membantu dalam penyelesaian tugas kuliah dan tugas akhir," katanya. Hal ini juga didukung dengan penyediaan informasi yang beragam sesuai dengan bidang studi masing-masing. Adapun responden yang menjawab tidak setuju mengatakan alasannya bahwa e-repository UIN Sunan Kalijaga kurang menyediakan informasi yang relevan. "Soalnya kalau pas lagi nyari sering tidak menemukan apa yang kita inginkan," ujarnya. Sehingga dalam hal ini pengguna tidak setuju jika e-repository ini dikatakan usefuness. Dari penjelasan para responden ini dapat disimpulkan bahwa e-repository perpustakaan UIN Sunan Kalijaga telah memenuhi indikator usefulness.

\section{b. Efisien}

Pada indikator ini, nilai yang sangat dipertimbangkan adalah mengenai kevalidan informasi yang disediakan dan kecepatan sistem dalam menampilkan informasi yang dibutuhkan pengguna (respon time). Hal ini dapat diukur bahwa semakin valid dan cepat e-repository menampilkan informasi, maka dapat dikatakan telah memenuhi kriteria efisien. Hasil angket menyebutkan bahwa banyak responden yang menyatakan setuju bahwa e-repository UIN Sunan Kalijaga memenuhi kriteria efisien, namun tidak sedikit juga yang berpendapat kurang setuju. Hal ini dapat dilihat dari hasil angket bahwa sebanyak 13 responden atau $28,2 \%$ yang menyatakan setuju dan sebanyak 12 responden atau $26 \%$ menyatakan kurang setuju. Hasil yang hampir seimbang ini disampaikan dengan beberapa alasan. Seorang responden yang menyatakan setuju berpendapat bahwa informasi yang tersedia pada e-repository ini valid dan dapat dipertanggungjawabkan serta mampu memenuhi kebutuhan informasi, namun untuk kecepatan/ respon waktu sistem dalam menampilkan informasi seringkali lambat. Namun, nampaknya hal ini tidak begitu menjadi masalah baginya karena informasi yang ada sangat membantu pekerjaannya.

Hal ini berbeda dengan responden yang menyatakan kurang setuju bahwa "Menurut saya erepository ini kurang membantu memenuhi kebutuhan informasi saya," katanya. Bahkan responden juga sempat meragukan tentang kevalidan dari sumber informasi yang disajikan. Begitu juga dengan masalah jaringan internet yang seringkali membuat lambat proses pengaksesan, sehingga sistem e-repository tidak mampu menampilkan informasi dengan cepat, sehingga dia sering merasa jengkel karena harus menunggu dengan waktu yang lama. "Kalau pas lagi ngakses sering lemot jaringannya. Jadi lama nunggu informasi keluar," terangnya. Dari hasil angket dan penjelasan responden ini dapat dikatakan bahwa e-repository perpustakaan UIN Sunan Kalijaga memenuhi kriteria efisien. 


\section{c. Efektif}

Pada indikator ini, keefektivan elektronik repository perpustakaan UIN Sunan Kalijaga Yogyakarta dapat diukur melalui kriteria kelengkapan dan minimnya eror yang dialami oleh pengguna. Kelengkapan informasi yang dimaksud merupakan keberhasilan e-repository dalam memenuhi seluruh kebutuhan informasi pengguna. Selain itu, e-repository ini dapat dikatakan efektif jika pengguna tidak banyak mengalami eror ketika mengaksesnya.

Berdasarkan hasil penyebaran kuesioner rata-rata responden menyatakan setuju bahwa e-repository ini telah memenuhi kriteria efektif yaitu sebanyak 20 responden atau 43,4\%, sedangkan responden yang menyatakan tidak setuju sebanyak 10 responden atau sebanyak 21,7\%. Lebih dari 50\% responden yang menyatakan setuju adalah responden yang sudah mengakses e-repository lebih dari 10 kali, sedangkan responden yang menyatakan kurang setuju mengaku baru mengakses e-repository sekitar 3-5 kali akses. Hal ini sangat berpengaruh dengan keterbiasaan pengguna saat mengakses, sehingga responden yang belum terbiasa menggunakan layanan e-repository lebih banyak mengalami eror.

Salah satu responden yang menyatakan setuju berpendapat bahwa layanan e-repository yang dimiliki perpustakaan UIN Sunan Kalijaga cukup membantu kebutuhan informasinya. Hal ini disampaikannya bahwa ia sering menyelesaikan tugas kuliahnya dengan mencari referensi dari e-repository ini baik berupa jurnal nasional maupun internasional. "Kalau saya sering cari referensi lewat e-repository ini. Soalnya sudah tersedia banyak tinggal pilih," ujarnya. Hal ini berbeda dengan responden yang menyatakan tidak setuju berpendapat bahwa layanan e-repository ini masih kurang membooming di kalangan mahasiswa, sehingga masih sedikit sekali yang mengetahuinya. Selain itu, layanan e-repository ini masih susah diakses bagi pengguna yang masih awam, sehingga ia tidak setuju apabila e-repository ini dikatakan efektif. "Iya harusnya ada semacam skema atau alur penggunannya, biar mudah diakses," ujar salah satu responden. Namun dari hasil penyebaran angket tersebut dapat disimpulkan bahwa e-repository perpustakaan UIN Sunan Kalijaga telah memenuhi indikator efektif.

\section{d. Learnability}

Kriteria learnability yang bisa dinilai pada e-repository diantaranya adalah kemudahan akses yang dilakukan oleh pengguna. Artinya bentul tampilan mulai dari pilihan menu atau petunjuk fitur-fitur mudah dipelajari dan tidak menyulitkan pengguna saat memanfaatkannya. Kemudahan akses menjadi salah satu faktor penting keberhasilan bagi penggunaan sebuah sistem layanan, karena apabila sistem mudah digunakan maka pengguna akan memanfaatkannya kembali di lain waktu.

Berdasarkan hasil penyebaran angket, rata-rata responden menyatakan tidak setuju jika erepository perpustakaan UIN Sunan Kalijaga mudah digunakan, yaitu sebanyak 19 responden atau 41,3\%. Adapun responden yang menyatakan setuju hanya sebanyak 6 responden atau 13\%. Ketika didalami lebih lanjut dengan bertanya kepada responden, mereka yang setuju dengan kriteria ini mengaku tidak asing lagi dengan e-repository, sehingga menurut mereka sangat mudah dipelajari dan digunakan. Mayoritas responden ini adalah dari kalangan dosen dan mahasiswa ilmu perpustakaan sendiri. 
Namun, berbeda halnya dengan responden yang menyatakan tidak setuju mengaku e-repository masih belum mampu menunjukkan kemudahan akses pada sumber-sumber informasi. Mereka mengaku masih belum paham bagaimana mengakses jurnal atau mencari jurnal yang berkualitas melalui e-repository. Selain itu, menurut mereka layanan e-repository perlu disosialisasikan penggunaannya atau diberikan petunjuk pada laman web-nya, sehingga pengguna tidak kebingungan ketika ingin mencari informasi yang mereka inginkan. Oleh karena itu, dari hasil penyebaran angket ini dapat disimpulkan bahwa e-repository perpustakaan UIN Sunan Kalijaga belum memenuhi kriteria learnability.

\section{e. Kepuasan}

Pada kriteria ini, e-repository dapat dinilai melalui kemampuan pengguna menikmati layanannya (enjoyable) saat menggunakannya. Kepuasan pengguna ini juga dilihat dari seberapa baik informasi diorganisir dan tampilan laman yang diberikan mulai dari tampilan warna dan pemilihan gambar atau font tulisan. Berdasarkan angket/kuesioner yang diberikan kepada responden didapatkan hasil bahwa sebanyak 15 responden atau 32,6\% menyatakan tidak setuju atau tidak puas, dan sebanyak 7 responden atau $13 \%$ menyatakan setuju atau merasa puas. Ketika melihat langsung laman web digital library UIN Sunan Kalijaga, tampilan warna yang digunakan adalah hijau dengan background halaman putih. Responden yang menyatakan tidak setuju berpendapat bahwa tampilan e-repository ini masih monoton dan tidak menarik. Menurutnya tampilan warna kurang bisa dinikmati dan tidak enjoyable. "Soalnya masih monoton, ya gitugitu aja tampilannya. Jadi kalau dibilang menarik menurut saya tidak,” jelasnya.

Berbeda dengan responden yang menyatakan puas dengan tampilan layanan e-repository ini berpendapat jika sebenarnya pemilihan warna atau bentuk tampilan bukan hal yang sangat penting, karena menurutnya ada yang lebih penting dari itu yaitu kelengkapan informasi dan kemudahan akses. Oleh karena itu, tampilan yang monoton atau tidak monoton tidak menjadi masalah baginya. Namun, dari analisis penyebaran kuesioner ini dapat disimpulkan bahwa e-repository perpustakaan UIN Sunan Kalijaga belum memenuhi kriteria kepuasan.

\section{Simpulan}

Berdasarkan hasil analisis data dan pembahasan yang dijelaskan diatas dapat disimpulkan bahwa salah satu cara untuk menilai performa sebuah layanan informasi seperti digital library atau elektronik repository miliki sebuah perpustakaan adalah dengan mengukur tingkat kegunaan (usability). Penilaian ini akan lebih obyektif jika dilihat dari perspektif pengguna. Penilaian tingkat usability pada elektronik repository (e-repository) dapat dilakukan dengan menilai beberapa indikator yaitu usefulness, efisien, efektif, learnability, dan kepuasan.

Berdasarkan hasil penyebaran angket/kuesioner ke-46 responden dapat disimpulkan bahwa erepository milik perpustakaan UIN Sunan Kalijaga Yogyakarta hanya memenuhi indikator usefulness, efisien, dan efektif namun tidak memenuhi indikator learnability dan kepuasan. Kelemahan pada indikator learnability dan kepuasan ini dirasakan oleh pengguna karena layanan e-repostory dianggap belum bisa diakses dengan mudah. Banyak responden yang belum paham bagaimana menggunakan e-repository mulai 
dari cara akses informasi hingga penelusuran ke jurnal-jurnal nasional maupun internasional. Kelemahan lain adalah pengguna belum merasa puas dengan kehadiran e-repostory. Tampilan yang monoton dan tidak menarik juga menjadi alasan. Namun kelebihan lain ditunjukkan oleh e-repository ini dengan menampilkan informasi yang lengkap dan valid sehingga sangat bisa dipertanggungjawabkan. Selain itu, informasi yang terorganisir seperti kebaruan dan keakuratan informasi sudah sangat cukup membantu pengguna dalam memenuhi kebutuhan informasinya.

\section{Rekomendasi}

Dari kesimpulan tersebut, maka peneliti dapat memberikan rekomendasi kepada pihak perpustakaan UIN Sunan Kalijaga Yogyakarta sebagai berikut:

1. Pada laman web digital library atau e-repository sebaiknya diberikan pilihan menu bantuan "help" agar bisa dimanfaatkan pengguna ketika mengalami kesulitan saat ingin mengakses informasi yang ada.

2. Promosi tentang keberadaan fasilitas e-repository sebaiknya lebih digencarkan, karena masih banyak sekali pengguna yang belum tahu kegunaan dari e-repository. Promosi ini dapat dilakukan dengan memasang banner di pintu masuk perpustakaan.

3. Kegiatan user education sebaiknya tidak hanya diberikan kepada mahasiswa baru, tetapi juga mahasiswa tingkat akhir yang lebih banyak membutuhkan akses informasi untuk tugas akhir. Hal ini bisa lebih ditekankan pada cara-cara mengakses jurnal internasional yang berkualitas.

4. Tampilan digital library atau e-repository sebaiknya didesain kembali dengan baik, mulai dari pemilihan warna dan font yang lebih menarik.

\section{Daftar Pustaka}

Abran, A. Khelifi and W. Suryn. 2003. "Usability meaning and Interpretations in ISO Standards Software Quality Journal, 11 (4) pp. 325-328.

Arikunto, Suharsimi. 2010. Prosedur Penelitian: Suatu Pendekatan Praktik. (Edisi Revisi). Jakarta: Rineka Cipta.

Arms, w. "Digital Libraries. Cambridge", 2000. Diakses dari http://www.cs.cornell.edu/wya/DigLib/index.html pada 02 April, 2017.

Borgman, C.L. 2001. "Interactive Design and Evaluation of a Geographic Digital Library for University Students: A Case Study of the Alexandria Digital Earth Prototype (ADEPT)," In Proceedings of the 5th European Conference on Research and Advanced Technology for Digital Libraries, London: Springer - Verlag, pp. 390-401

Blandford, et.al. 2004. "Analytical Usability Evaluation for Digital Libraries: A Case Study,” In Proceeding of the Fourth ACM/IEEE Joint Conference on Digital Libraries. New York: ACM Press, pp. 27-36. 
Burgoon, J.K, et.al. 2000. "Interactivity in Human-Computer Interaction: A Case Study of Credibility, Understanding and Influence," Computers in Human Behaviour, 16, (6) pp. 553-574.

Dicks, R.S. 1986. "Mis-usability: on the Uses and Misuses of Usability Testing," In Proceeding of the 20th Annual International Conference on Computer Documentation, ACM, Toronto, pp. 26-30.

Jeng, J. 2005. "Usability Assessment of Academic Digital Libraries: Effectiveness, Efficiency, Satisfaction, and Learnability," Libri, 55, pp. 96-121.

Long, H. 2002. "An Assessment of the Current State of Digital Library Evaluation,”. Diakses dari http://www.uni.edu/neuhaus/digitalbibeval.html pada 02 April 2017.

Marchionini, et.al, 2001. "Eevaluating Digital Libraries: A Longitudinal \& Multifaceted View, “ Library Trends, 49 (2), pp. 304-333.

Martono, Nanang. 2011. Metode Penelitian Kuantitatif. Jakarta: PT Raya Grafindo Persada.

Nielsen, J. 1993. Usability Engineering. London: Academic Press Limited.

Patrelli, D. 2008. "On the Role of User-centred Evaluation in the Advancement of Interactive Information Retrieval," Information Processing and Management, 44 (1), pp. 23-38.

Pipino, L, Y.W Lee, and R.Y Wang. 2002. "Data Quality Assesment," Communications of the ACM, 45 (4), PP. 211-218.

Reeves, et.al. 2005. "Evaluating Digital Libraries: A User - Friendly Guide. The University of Georgea, National Science Digital Library (NSDL.ORG).

Rogers, R and P. Hugh. 2008. "Usability Analysis for Redesign of a Caribbean Academic Library Website: A Case Study: OCLC Systems \& Services: International Digital Library Perspectives, 25 (3): 274293.

Savolainen, R. 2008. "Source Preference in the Context of Seeking Problem-specific Information", Information Processing and Management, 44 (1), pp. 274-293.

Seffah, A. 2006. 2006. "Usability Measurement and Metrics: A Consolidated Model. Software Quality Journal, 14 (2), pp. 159-178.

Sulistyo-Basuki. 2006. Metode Penelitan. Jakarta: Wedatama Widya Sastra.

Theng, Y.L. 2000. "Purpose and Usability of Digital Libraries," In Proceedings of the Fifth ACM Conference on Digital Libraries. New York: ACM Press, pp. 238-239.

Thornley, C, and F. Gibb. 2007. "A Dialectical Approach to Information Retrieval," Journal of Documentation, 63 (5) pp. 755-764.

Tombros, A, i. Ruthven and J.M. Jose. 2004. "How Users Assess Web Pages for Information Seeking," Journal of the American Society for Information Science and Technology, 56 (4), pp. 327-344. 
Umar, Husein. 2007. Metode Penelitian untuk Skripsi dan Tesis Bisnis. Jakarta: PT. Raja Grafindo Persada.

Yang, et.al. 2005. "Development and Validation of an Instrument to Measure User Preceived Service Quality of Information Presenting Web Portals,” Information and Management, 42 (4), pp. 575-589. 